\title{
Aktif İşgücü Piyasası Politika Uygulamalarının Etki- lerinin Değerlendirilmesi: Bir Meta Analiz Çalışması
}

DOI: 10.26466/opus.338656

\section{Hasan Bilgehan Yavuz}

${ }^{*}$ Yrd. Doç. Dr., Adana Bilim ve Teknoloji Üniversitesi, İşletme Fakültesi, Adana/Türkiye E-Posta: hbyavuz@adanabtu.edu.trＯRCID: 0000-0003-4011-7126

Öz

Bölüşüm sorunları ile birlikte 18.Y.Y dan itibaren ekonomilerin en önemli sorunlarından biri haline gelen işsizlik sorununun çözümü için gelişmiş ve gelişmekte olan ülkelerde en fazla uygulanan politika Aktif İşgücü Piyasası Politikalarıdır. Ülke bazında ve program çerçevesi kapsamında değişiklikler gösterse de, Aktif işgücü piyasası politikaları genellikle iş arama yardımları, mesleki eğitimler, kamu ve özel sektör iş yaratma sübvansiyonlarından oluşmaktadır. Bu çalışma ile farklı programlar kapsamında uygulanan politikaların etkileri konusunda meta analiz çalışması yapılmıştır. 77 farklı çalışmanın derlenmesi ile yapılan analizde hem pozitif hem negatif etkilerin varlığı tespit edilmiştir.

Anahtar Kelimeler: İşsizlik, istihdam, aktif işgücü piyasası politikaları, meta analiz, etki değerlendirmesi 


\title{
Assessment of the Impacts of Active Labor Market Policy Practices: A Meta Analysis Study
}

DOI: $10.26466 /$ opus.338656

\begin{abstract}
Active labor market policies are the most applied policy for developed and developing countries to solve the problem of unemployment that has become one of the most important problems of the economies since 18th century with the problems of distribution. Active labor market policies often consist of job search assistance, vocational training, public and private sector job creation subsidies, although they vary from country to country and from program framework to scope. In this study, a metaanalysis study was carried out on the effects of the policies applied within different programs. The analysis of 77 different studies showed that both positive and negative effects were found.
\end{abstract}

Key Words : Unemployment, employment, active labor market policies, meta analysis, impact evaluation 


\section{Giriş}

Feodalitenin varlığını sürdürdüğü tarım toplumlarında, bugünkü anlamıyla bir işsizlik probleminden bahsetmek mümkün değildir. Ancak 18. Ve 19. Y.Y. lar da bilim ve teknolojide yaşanan gelişmelerin yanı sıra sanayi devrimi ile birlikte ekonomilerde üretim artmaya başlamıştır. Artan üretim ile birlikte yeni ekonomik aktiviteler gündeme gelmiş ve elde edilen gelirin bölüşülmesi sorunlar baş göstermiştir. Bu bölüşüm sorunları ile birlikte işsizlik bir sorun olarak toplumsal hayatta konuşulmaya başlanmiştır.

Tarihsel olarak genellikle düşük seviyelerde seyreden işsizlik oranları özellikle 1929'da ABD'de başlayan büyük buhran ile önemli bir sosyal problem olarak ortaya çıkmıştır. Dönemin hakim iktisadi anlayışı olan Keynesyen iktisat kamu yatırımlarını ve dolayısıyla kamu istihdamını arttıracak tedbirlerle hem krizin atlatılacağını hem de ekonomik büyüme sağlanarak işsizlik gibi diğer problemlerin de çözüleceğini ileri sürmüştür.

Keynesyen iktisadın politika önerileri ve II.Dünya Savaşı sebebiyle bir süre gündemden düşen işsizlik sorunu, 1973 yılında yaşanan petrol şoku ile yeniden dünya ekonomilerinin çok önemli bir sorunu olarak gündeme gelmiştir. Özellikle gelişmiş ve gelişmekte olan ülkeler başka sosyal problemlere de sebep olan bu sorunun çözümü için adımlar atmaya başlamıştir.

İşsizlik sorununun çözümü için aktif ve pasif olarak sınıflandırılacak pek çok politika önerisi ortaya atılmıştır. Pasif politikalar genellikle bir transfer ödemesi niteliğinde harcama gerektirdiğinden etkinliği eleştirilmiş ve çok fazla uygulama alanı bulamamıştır. Buna karşın ilk olarak 1973 yılında İsveç istihdam bürosu şefi olan Gösta Rehn tarafından ileri sürülen Aktif İşgücü Piyasası Politikaları (A.İ.P.P.), işgücü piyasalarına işlerlik kazandırmak ve istihdamı arttırmak üzere gelişmiş ve gelişmekte olan pek çok ülke tarafından benimsenerek uygulanmaya başlanmıştır (Martin, 2014).

İlk uygulamalarını İsveç'te gördüğümüz A.İ.P.P. lerin Avrupa Birliği, OECD, Dünya Bankası gibi uluslararası örgütler tarafından da benimsenerek işsizliği azaltacak ve istihdamı arttıracak tedbirler olarak benimsendiği görülmektedir. Özellikle Avrupa Birliği tarafından yapılan çalışmalar 
sonucunda 1989 yılında yayınlanan İşçilerin Temel Sosyal Hakları Avrupa Komisyonu Şartı belgesindeki işçi deklarasyonu ile işgücü piyasaları ile ilgili oluşturulan stratejilerin temelinde A.İ.P.P. larının olduğu görülmektedir (Addison \& Siebert, 1999). Oluşturulan bu strateji ile; insan kaynağ1nın geliştirilmesi için fonlar oluşturulması gerektiği, işyerinde kalite ve verimliliği geliştirecek tedbirlerin alınması, tam istihdamın sağlanması ve yeni iş yaratma potansiyelinin arttırılarak işgücü piyasasının kapsamının geliştirilmesi gerektiği belirtilmiştir (Franzese \& Hays, 2006).

Avrupa Birliği İstihdam Stratejisinin belirlenen hedeflerine ulaşabilmesi için uygulanacak politika uygulamaları Aktif ve Pasif olarak ikiye ayrılmıştır. Pasif politikalar; genellikle işsizlik yardımları ve emeklilik ödemeleri gibi işgücü piyasalarına işlerlik kazandırma amacından çok, işçilerin hayat standartlarında yaşanabilecek aşırı düşmelerin engellenmesine yönelik politikalar olarak karşımıza çıkmaktadır (Yavuz, 2015).

Türkiye' de işsizlik sorununu çözümü için yapılan çalışmalara baktı̆̆gmızda ise; uzun yıllar boyunca işsizlik sorunun çözecek etkin bir istihdam politikası uygulanmamış olmakla beraber, 2002 yılında İŞ-KUR tarafından başlatılan istihdam politikaları kapsamında, Avrupa İstihdam Stratejisine uygun olarak Aktif İşgücü Piyasası Politikalarını uygulanmaya başlamıştır (Eser \& Terzi, 2008).

İşsizlik sorunu ve bu sorunun çözümü için oluşturulan A.İ.P.P. lerin tarihsel gelişimine kısaca baktıktan sonra, çalışmanın ikinci bölümünde aktif işgücü piyasası politikalarına daha ayrıntılı bakılacaktır. Çalışmanın son bölümünde A.İ.P.P. lerin işsizlik sorununun çözümüne yaptığ1 katk1lara ilişkin yapılmış değerlendirme çalışmalarının incelendiği bir meta analiz yapılmıştır.

\section{Aktif İşgücü Piyasası Politikaları:}

İşsizlik sorununun çözümü için yoğun çaba harcayan sanayileşmiş ülkeler özellikle son on yılda GSYİH'larının önemli bölümlerini Aktif istihdam politikalarına ayırmıştır. Bu politikalar pek çok ülke açısından, uzun dönemli işsizliği azaltmak amacıyla, düzenli işsizlik yardımları olarak bilinen pasif politikaları ikame etmek üzere kullanılmıştır. Uygulamalar ço- 
ğunlukla uzun dönemli işsiz kalanlar, firma kapanması sebebiyle işsiz kalanlar ve toplu olarak işten çıkarılan çalışanlar açısından dizayn edilmiştir (Dar, Gill, 1998).

Aktif İşgücü Piyasası Politikaları genel anlamda yeni iş yaratacak, iş aramayı kolaylaştıracak, işçi niteliğini böylece de verimlilik ve ücretleri arttıracak politikalar olarak karşımıza çıkar. Bengsston (2012) çalışmasinda A.İ.P.P. lerin sosyal ve demokratik refah devletinin bir gereği olarak geliştiğini ileri sürmüştür. AİPP’lerin evrensel amac1; işgücü niteliğini arttırmak, işgücü arzını arttırmak ve işgücü piyasalarının işleyişini iyileştirmektir. Ancak farklı ülke uygulamalarında daha spesifik alanlarda, özellikle engelliler, gençler, eğitim almamış olanlar vb. dezavantajlı kişiler açısindan farklı amaçlarla da AİPP'lerin uygulandığı görülmektedir. Örneğin bu programlar Günay Avrupa ve Anglosakson ülkelerinde sıkı istihdamı koruma yasaları ile birlikte uygulanırken, İskandinav ülkelerinde güvenceli esneklik politikaları benimsenerek uygulamalar yapılmıştır (Greve, 2012; Bengsston, 2012; Bergeman, Berg, 2006; Calmfors vd., 2001).

Aktif işgücü piyasası politikaları konusunda ülke uygulamalarına bakıldığında, engellilere, kadınlara, gençlere, eğitimsiz bireylere ve bunlara benzer dezavantajlı kesimlere yönelik yapılan özel uygulamalar da dikkati çekmektedir. Genel uygulama açısından benzer programlar, dezavantajlı kesimler açısından pozitif ayrımcılık yapılarak, küçük değişiklik ve avantajlarla uygulandığı görülmektedir. Bu uygulamalardan bazıları, dezavantajlı kişilerin işgücü piyasalarına katılımını sağlamak amacı güderken, bazı uygulamaların sadece sosyal devletin bir gereği olarak sosyal adaleti sağlamaya yönelik uygulandığı görülmektedir. Bu tür uygulamalar aktif olarak tanımlanmasına rağmen, barındırdığı amaç açısından pasif işgücü piyasası politikası olarak görülebilir (Islam vd., 2001; Hogelund, Pederson, 2002).

Bununla beraber, genel kabul gören dört alanda A.İ.P.P. uygulamalarından bahsedeceğiz. Bu alanlar (Spevacek, 2009);

1. Özel işletmelere verilen, ücret ve istihdama ilişkin sübvansiyonlar ile ek istihdam sağlanması,

2. Kamu kesiminde ek istihdam yaratılması,

3. Eşleştirme, iş danışmanlığ 1 ve iş arama yardımları,

4. Beceri geliştirecek eğitimler. 


\section{1. Ücret ve İstihdam Sübvansiyonları:}

Belirli sektörler için getirilen uygulama ile, ilgili sektörde çalışan işletmelere, çalıştıracakları her ek işçi için, hükümet tarafından sağlanan sübvansiyonları içerir. Bu sübvansiyonlar, sigorta ödemelerinin hazine tarafından karşılanması, vergi indirimleri gibi uygulamaları içerir. Bu sübvansiyonlarla firma açısından işgücü maliyetleri düşürülerek, hem üretilen mal ve hizmetlerin fiyat artışları kontrol altına alınarak rekabet avantajı yaratılmakta, hem de firmalar açısından düşük maliyetle ek istihdam yaratılması amaçlanmaktadır.

Bu politika uygulamasında bazı dışlama etkilerinden de söz etmek gerekir. Örneğin firma söz konusu sübvansiyonlardan yararlanmak için mevcut çalışanlarını işten çıkarma eğiliminde olabilir. Yine sübvansiyondan yararlanamayan firmalar açısından maliyet artışları, bu firmaların işçi çıkarmasına veya üretim azalmasına sebep olabilir (Karabulut, 2007).

\subsection{Kamu İstihdam Hizmetleri:}

A.İ.P. kapsamında özellikle desteklenen sektörler açısından iş ve ücret imkanı sağlamak üzere kamuda işe alımlar yapılabilir. Burada temel amaç, iş bulabilecek niteliklere sahip olamayan kişilerin, belirli ve özellikle niteliksiz işler açısından, kamuda istihdam edilmesini sağlayarak işsizliğin azaltılması ve kişilere iş ve gelir sağlanarak talebin ve dolayısıyla üretimin arttırılmasıdır.

Uygulanan bu programlar ile geçici de olsa istihdam yaratılmasının yanı sıra, katılımcıların uzun süre çalışma hayatından koparak yaşanabilecek uzun dönemli olumsuz etkilerinde ortadan kaldırılması mümkün olmaktadır. Yine bu programların temel amaçlarından birisi olarak, dezavantajlı (engelli, eğitimsiz, yaşlı vb.) kişilere yönelik olarak uygulanan sosyal bir program olma özelliği taşımasıdır (Karabulut, 2007).

\subsection{Eşleştirme ve İş Danışmanlığı Hizmetleri:}

Hükümet tarafından kurulan istihdam büroları aracılığıyla, iş arama konusunda bilgi eksikliği olan kişiler ile işçi aramak konusunda bilgi eksik- 
liği olan firmaların bir araya getirilerek (eşleştirilerek) istihdam sağlanması amaçlanmaktadır. Bu uygulama ile, iş uzmanları tarafından hem firmalara hem kişilere danışmanlık hizmeti verilerek, uygun işlere uygun işçilerin yerleştirilmesi yani iş ile işçinin eşleşmesi sağlanmaktadır.

İş uzmanları tarafından verilecek danışmanlık hizmeti ile işgücü piyasalarında oluşan asimetrik bilgi probleminin çözümüne de katkı sağlanacaktır. Çünkü; firmalar işe alacakları kişilerin nitelikleri hakkında tam bilgiye sahip olmak isterler, yine işçiler de işe girecekleri firmalar hakkında bilgi sahibi değildir. İşte iş uzmanları bu bilgi eksikliklerini giderecek uygun kurumsal yapılar oluşturabilirler. Böylelikle, iş uygun eleman bulma konusundaki maliyetler ile, iş arama maliyetleri minimuma indirilebilecektir (Yavuz, 2017).

\subsection{Mesleki Eğitim Programları:}

Üretim sektöründe ihtiyaç bulunan alanların tespit edilerek, bu alanlara uygun nitelikte eleman temin etme konusunda önemli bir politika uygulamasıdır. Burada sektörel incelemeler yapılarak firmaların ihtiyaç duyduğu nitelikler tespit edilir. Bu tespitlere istinaden mesleki eğitim programları düzenlenir. Bu programları başarı ile tamamlayan bireylerin hem iş bulmaları hem de etkin ve verimli çalışmaları sağlanmış olur. Yine firmalar açsısından değerlendirdiğimizde, firmalar ihtiyaç duyulan alanlarda daha kalifiye elemanlar ile üretim yapılmış olur.

Belirli niteliklerden (özellikle işgücü piyasalarının ihtiyaç duyduğu alanlarda) yoksun olma, uzun dönemli işsizliği en önemli sebeplerinden birisidir. Bu eksiklik aynı zamanda üretim piyasları açısından da etkinlik kaybı anlamına gelmektedir. Kamunun sağlayacağı mesleki eğitim programları bu açıdan bakıldığında hem işgücü hem de üretim piyasaları açısından en faydalı program uygulamaları arasında yer almaktadır. Ancak bu eğitim programlarının amaçlarına ulaşabildiği konusunda tartışmalar mevcuttur (Kluve, 2014).

Mesleki becerilerin geliştirilmesi programı, Avrupa'da bütün hükümetler tarafından kullanılan ve en yüksek bütçelerin tahsis edildiği programlardır. Bu programlar işgücü piyasasında çalışan olsun işsiz olsun her- 
kesin becerilerinin korunması ve geliştirilmesi amaçlanmaktadır. Bu programlar özellikle açık ekonomilerde uzun dönemli işsizliği engelleyecek önemli politika uygulamalarıdır (Blache, 2011).

\section{Aktif İstihdam Politikalarının Etkinliğinin Değerlendirilmesi:}

Genellikle uygulanan bir programın değerlendirilmesi için, programın özelliğine göre farklı yöntemler önerilir. Örneğin süreç değerlendirme, fayda-maliyet analizi, performans izleme, etki değerlendirmesi gibi yöntemler programın amaçlarına ve yapılan değerlendirmenin amaçlarına göre yapılan farklı uygulamalardır. A.İ.P.P. perspektifinden baktığ1mızda, politika uygulamalarının amaçları ve yapılacak değerlendirme çalışmasının amaçları göz önüne alındığında, bizim de bu çalışmada ki amacımız A.İ.P.P. uygulamalarının işsizliği azaltma veya istihdamı arttırma şeklinde ortaya çıkacak etkinliğinin değerlendirilmesidir.

Etkinlik değerlendirmesi iki açıdan yapılabilir. Birincisi makro ekonomik açıdan ikincisi ise mikro ekonomik açıdan yapılan değerlendirmelerdir. Makro ekonomik açıdan yapılan değerlendirmede, programların istihdam, işsizlik, ücretler, verimlilik gibi makro ekonomik değişkenler açısından bir değerlendirme yapılır ve politika uygulamalarının sosyal etkilerine odaklanılır. Mikro ekonomik değerlendirmede ise; program katılımcıları perspektifinden bir değerlendirme yapılarak katılımcıları istihdam edilmesi, elde ettikleri gelirler açısından sağlanan artışlar gibi konular değerlendirmeye tabi tutulur (Tachizadeh, 2014; Forslund, Krueger, 2008).

Yapılacak değerlendirme çalışmalarında sonuçların hatalı çıkmasını sağlayan bazı kısıtlar söz konusu olabilmektedir. Akbaş (2015) tez çalışmasında, Aktif İstihdam Politikalarının etkileri konusunda yapılacak çalışmalarda, sonuçların hatalı çıkmasına sebep olacak bazı program etkilerinden bahsetmiştir. Bu etkilere kısaca bakacak olursak;

1. Programa katılan bir kişinin aslında programa katılmayan ancak işe alınacak kişinin yerine istihdam edilmesini açılayan ikame etkisi,

2. Sübvansiyon olmadan da işe alınarak çalışacak bir kişi için sübvansiyon ödenmesi durumunu açılayan etkinlik kaybı, 
3. Sübvansiyon sağlanan sektörlerde çalışan firmaların rekabet avantajı elde ederek, sübvansiyondan yararlanamayan firmaları piyasadan kovmasına sebep olan yer değiştirme etkisi,

4. Değerlendirme yapılmak üzere seçilecek deney ve kontrol gruplarının seçimlerinde yaşanan seçim yanlılığı problemi,

5. Değerlendirme aşamasında seçilmiş olan katılımcıların oluşturduğu deney grubunun, bunun bir deney çalışması olduğunu bildiği için davranışlarını değiştireceğini söyleyen Howtrone etkisi,

6. Programın uygulanmadığı coğrafi bölgelerde veya sektörlerin olduğu yerlerde yaşayan işsiz bireylerin, programın uygulandığı bölgelere göç etmesine sebep olan kilitlenme etkisi,

7. Uygulanan programlar sayesinde işgücü arzının artarak ücretlerin düşmesine sebep olacak çekme etkisi,

Aktif işgücü piyasası politikalarının dışsallıkları olarak ta adlandırılabilecek bu etkiler, değerlendirme çalışmaları açısından göz ardı edilmiştir.

Bu çalışma ile, Aktif İstihdam Politikası uygulamaları konusunda yapılan mikro analizlerin, ikinci bölümde sayılan politika uygulamaları konusunda yapılmış uygulamalar konusunda bir meta analiz yapılması amaçlanmıştır. Yapılacak analiz ile uygulanan politika araçlarından hangilerinin daha etkin sonuçlar verdiği konusu incelenmiştir. Bu amaçla öncelikle meta analiz konusunda kısa bir bilgilendirme yapılarak sonuçlar paylaşılacaktır.

\section{Meta Analiz}

Meta Analiz; belirli bir konuda birbirinden bağımsız olarak yapılmış çalışmaların sonuçlarının birleştirilerek yeni bir istatistiksel analiz yapılmasıdır. Meta analiz literatür taraması yöntemine istatistik yöntemlerinin eklenmesi ile ortaya çıar. Meta analiz yapabilmek için öncelikle sistematik bir derleme yapılması gerekir. Bu derlemede hangi çalışmaların analize dahil edileceği, analizin amaçlarına uygun kriterlerle belirlenerek, sonuçları etkileyecek kapsamda olan çalışmaların analiz dışı bırakılması gerekmektedir (Tachizadeh, 2014).

Meta analiz çalışmalarına konu edilen bağımsız çalışmalarda, A.İ.P.P.'nın katılımcılarına, katılımcı olmayanlara kıyasla nasıl sonuçlar 
alındığı araştırılmıştır. Bu çalışmalarda genellikle yukarıda sayılan dört A.İ.P.P.'nin katılımcılarının istihdam durumları, yeniden istihdamları ve ücret seviyeleri üzerindeki etkileri analiz edilmektedir (Calmfors vd., 2014).

Yapılan literatür taramasında ülke bazlı, bölge bazlı ve genel meta analizlerin yapıldığı görülmüştür. Örneğin Calmfors vd. (2001) çalışmasında A.İ.P.P. lerin mikroekonomik ve makroekonomik etkilerini analiz eden çalışmalar ayrı ayrı incelenmiştir. Mikro analize konu olan çalışmlara katılımcıların yaş, cinsiyet, eğitim durumu, gelir durumu gibi değişkenleri dikkate alınarak politika uygulamalarından nasıl etkilendiği konusunda bir yargıya varılmaya çalışılmıştır. Makro ekonomik analizlerde ise A.İ.P.P. harcamalarının işsizlik oranlarını, istihdam seviyesini ve ücretleri nasıl etkilediği konusundaki çalışmalar derlenmiştir. Yine Betcherman vd. (2004) çalışmalarında daha önceden yapılmış meta analizlerde kullanılan 87 çalışma yeniden incelenmiş, bu çalışmalara yeni yapılmış 39 çalışma daha eklenerek bir meta analiz yapılmıştır. Bu çalışmada yapılan analizde A.İ.P.P. lerin bütün detaylı uygulamaları, yani kadınlara yönelik veya düşük eğitimlilere yönelik programlar yada belirli bir coğrafyada yaşayanlara yönelik olarak uygulanan farklı program uygulamaları dikkate alınarak bir analiz yapılmıştır.

Caro vd. (2010) çalışmasında da dönemsel program uygulamalarını dikkate almak suretiyle, 1995-2007 yılları arasında yapılan çalışmaları dikkate alarak 199 programın etkisini inceleyen 97 çalışma ile ilgili bir meta analiz yapmıştır.

Vooren vd. (2016) çalışmalarında 1990-2015 yılları arasında yapılmış 35 çalışmayı inceledikleri analizlerinde analize dahil edilen çalışmalarla ilgili eleme kriterleri belirlemişlerdir. Örneğin yarı deneysel değerlendirme çalışmaları, İngilizce basılmış çalışmalar gibi kriterlerle meta analiz yapılmiştır.

Tachizadeh (2004) çalışmasında 1997-2013 yılları arasında uygulanan 53 programın değerlendirildiği 22 çalışma derlenerek meta analiz yapılmıştır. Seçilen çalışmalar A.İ.P.P uygulamalarından eğitim programları, iş arama yardımları ve istihdam yaratma etkinliklerini değerlendiren çalışmalar dikkate alınmıştır.

Bu çalışmada da ülke, tarih, yaş, cinsiyet, eğitim vb kriterler dikkate alınmamıştır. İkinci bölümde belirtilen A.İ.P.P. uygulamalarının biri veya 
birden fazlasını istihdam, işsizlik ve ücretler açısından değerlendiren çalışmalar dikkate alınmıştır. Genellikle Avrupa Birliği ve OECD ülkelerinde uygulanan A.İ.P.P. ler için değerlendirme çalışmaları da bu ülkeleri kapsamaktadır. Çalışmaya dahil edilen analizlerle ilgili ayrıntılı bilgiler sonuç bölümünde verilmektedir. Analiz kapsamında incelenen çalışmalar ve sonuçlarını gösteren tablo ek- de verilmiş ve yararlanılan kaynaklar çalışmanın kaynakçasından ayrı olarak ek-2 de verilmiştir.

\section{Sonuç ve Yorum}

Analiz çalışmasına dahil edilen 77 çalışmanın çoğunluğu 2000'li yıllardan sonra yapılan çalışmalardır. Yine bu çalışmaların 52 tanesi Avrupa ülkeleri 15 tanesi Amerika kıtasında bulunan ülkeler ile ilgili uygulanmış A.İ.P.P. lerin değerlendirme çalışmalarını içermektedir.

İncelenen çalışmalarda kısa dönem-uzun dönem, erkek-kadın, yaş grubu, özür grubu gibi farklı kriterlerde farklı sonuçlar elde edilmiştir. Programlardan toplam 117 etki hakkında sonuç verilmiştir. Bu 117 etkinin $\% 74,2$ si istihdamla ilgili, $\% 25,8$ i ise ücretlerle ilgilidir.

İstihdamla ilgili çalışmaların $\% 58,9$ sinde pozitif, $\%$ 13,8 sinde negatif etki bulunmuştur. Çalışmaların geri kalan kısmında \% 3,3 oranında önemli pozitif etki, \% 10,3 sında önemsiz pozitif etki bulunmuş ve \% 13,7 sinin etkisiz sonuç bulunduğu görülmüştür.

A.İ.P.P. lerin ücretlere olan etkisini inceleyen çalışmalarda ise; $\% 65,6$ oranında pozitif etki, \% 4,1 negatif etki \% 4,2 önemli pozitif etki, \% 8,7 önemsiz pozitif etki ve $\% 17,4$ oranında ise etkisiz sonuç bulunduğu görülmüştür.

Pozitif etki uygulanan A.İ.P.P. larının istihdamı arttırdığı (işsizliği azalttığı) veya ücretleri arttırdığı anlamına gelmektedir. Çalışmaların incelenmesi neticesinde pozitif etkilerin genellikle dezavantajlı kişiler üzerine uygulanan çalışmalardan elde edildiği görülmüştür. Örneğin hiç eğitim almamış kişilerin veya çalışma çağına yeni girmiş kişilerin, engellilerin, çok fakir bölgelerde yaşayanlarla ilgili yapılmış çalışmalarda pozitif sonuçlar bulunmuştur.

Negatif sonuç ise A.İ.P.P. lerin dışsallıklarına vurgu yapmaktadır. Yani uygulanan A.İ.P.P. sonucunda işten çıkarmaların yada ücret seviyelerinin düşmesi söz konusudur. Bu sonuçlar ise en fazla belirli bir eğitim yada 
gelir seviyesine sahip kişilerin veya yeniden istihdam sağlanan kişilerin katılımcı olduğu programlarda gözlenmektedir. Bir örnek vermek gerekirse; programın uygulandığı bölge yada sektördeki firmalar, programların parasal getirilerinden faydalanabilmek için mevcut çalışanlarını işten çıkararak düşük maliyet ve ücretlerle program katılımcılarını ile almaları sonucunu doğurmaktadır.

Yine analizde gözlemlenen bir diğer sonuç ise; program uygulamalarının kısa dönemlerde yaptırımları nedeniyle pozitif sonuçlar verdiği, ancak uzun dönemde yükümlülükler ortadan kalkınca istihdam ve ücretlerin eski seviyelerine gerilediği görülmektedir.

Program uygulanan ülkelerin özelliklerine bakıldığında nüfus yoğunluğu ve işsizlik oranları düşük olan ülkelerde daha fazla olumlu sonuç alındığı görülmektedir. Ülke uygulamaları içerisinde en fazla dikkat çeken İsveç'tir. Burada ki politika uygulamaları genellikle aktif ve pasif önlemlerin karma olarak uygulandığı ve birkaç programın aynı anda uygulanarak katılımcısı için bazı yükümlülükleri de içerdiği görülmektedir.

Aktif işgücü piyasası politikalarının işsizliği azaltma, istihdamı arttırma ve ücretleri iyileştirme konularında pozitif etkisi yadsınamaz, ancak bu politika uygulamaları açısından fayda maliyet analizlerinin yapılması ve uzun dönemli istihdama katkı sağlayacak önlemlere öncelik verilmesi gerektiği düşünülmektedir.

\section{KAYNAKÇA}

Addison, J.T. \& Siebert, S. (1999). Recent development in social policy in the New European Union, Industrial and Labour Relation Review, $48(1), 5-27$.

Akbaş, S. (2015). Aktif İşgücü Piyasası Politikalarının Etki Değerlendirmesi: Denizli İli Örneği. Pamukkale Üniversitesi, Sosyal Bilimler Enstitüsü, Çalışma Ekonomisi ve Endüstriyel İlişkiler Anabilim Dalı Yüksek Lisans Tezi.

Bengsston, M. (2012). Transformation of labour market policies in the Nordic Countries: Towards a regime shift in Sweden and Denmark. University of Gottenborg, Department of Sociology and work science

Bergeman, A.\& Berg, G.J. (2006). Active Labour Market Policy Effect For Women in Europe. A Survey. IZA Discussion Paper No:2365 
Calmfors, L., Forslund, A. \& Hemström, M. (2004). The effect of active labour market policies in Sweden. What is the evidence? Erişim Tarihi: 18.08.2017, Erişim: www.mitpress. mit.edu/sites/default/files/titles/content

Caro, D., Kluve, J. \&Weber, A. (2010). Active Labour Market Policy Evaluation: A Meta Analysis. NBER Working Paper 16173

Dar, A. \& Gill, I.S. (1998). Evaluating retraining programs in OECD countries: Lessons, Learned. The World Bank Reaserch Observer, Vol.13, No.1, P.79-101

Eser, B.Y. ve Terzi, H. (2008). Türkiye'de işsizlik sorunu ve Avrupa İstihdam Stratejisi. Erciyes Üniversitesi İktisadi ve İdari Bilimler Fakültesi Dergisi, 30,229-250.

Fawcett, C.S. (2002). Latin America youth in transition: A policy paper on youth unemployment in Latin America and The Caribbean. InterAmerican Development Bank

Forslund, A. \& Krueger, A.B. (2008). Did active labour market policies help Sweden rebound from depression of the early 1990s? CEPS Working Paper No:158

Franzese, R.J. \& Hays,J.C. (2006). Strategic interaction among EU goverments in Active labour market policy making. European Union Politics, 7(2), 167-189.

Greve, B. (2012). Denmark a Nordic welfare state. Are the active labour market policy withering away? The Open Social Science Journal, 5, 15-23

Hogelund,J. \& Pederson, J.G. (2002). Avtive Labour Market Policies for disabled people in Denmark. The Open Labour Market Working Paper 18

Islam, R., Krishnamurty,J. \& Purı, S. (2001). Active Labour Market Policy in East and South Asia: What has been done and what can be done? The World Bank ILO-JMOL-PDOLE Seminar on Labour Market Policies

Karabulut, A. (2007). Türkiye'de İşsizliği Önlemede Aktif İstihdam Politikalarının Rolü ve Etkinliği. Türkiye İş Kurumu Genel Müdürlüğü Uzmanlık Tezi 
Kraus, F., Patrick, P. Ve Steiner, V. (1999). Employment effects of publicly financed training programs-The East German Experience. Journal of Economics and Statistics, Vol.219, Issue 1-2, 216-248

Martin, J. P. (2014). Activation and Active Labour Market Policy in OECD Countries: Stylized Facts and Evidence on Their Effectivenes. IZA Policy Paper No:84

Spevacek, A.M. (2009). Effectivenes of Labour Market Programs. A Review of Programs in Control and Eastern Europe and The Commenwealth of Independent Strategy. USAID Knowledge Services Center

Tachizadeh, R. (2014). AB İstihdam Stratejisi Kapsamında Aktif İşgücü Piyasası Politikalarının Etkinliği. Meta analiz Yöntemiyle Bir Değerlendirme. Ankara Üniversitesi, Sosyal Bilimler Enstitüsü, Çalışma Ekonomisi ve Endüstriyel İlişkiler Anabilim Dal, Doktora Tezi.

Vooren, M., Haelermans, C. \& Groot,W. (2012). The effectivenes of active labour market policies: A systematic meta analysis. Erişim: www.cemopre.iseg.ulisboa.pt/educonf/4e3/files/papers/vooren.pdf Erişim Tarihi: 16/08/2017

Yavuz, H.B. (2015). Avrupa Birliği İstihdam Politikaları. Çukurova Üniversitesi İktisadi İdari Bilimler Fakültesi Dergisi, Cilt:19, Sayı:2

Yavuz, H.B. (2017). Information Problems in Competitive Markets and Their Impact on Labor Markets. ECOIE 2017, European Congress for Economic Issues: Unregistered "Youth" Employment: Impacts, Policies, Remedies and Local Practise, 30 March-1 April 2017, Kocaeli/Turkey. 


\section{Ek-1}

Tablo 1. Analiz kapsamında incelenen çalışmalar

\begin{tabular}{|c|c|c|c|}
\hline ÇALIŞMA & PROGRAM-DÖNEM-ÖRNEKLEM & $\begin{array}{l}\text { BAĞIMLI } \\
\text { DEĞİŞ- } \\
\text { KEN }\end{array}$ & SONUÇ \\
\hline $\begin{array}{l}\text { Aedo, Nunez, } \\
\text { (2004) }\end{array}$ & $\begin{array}{l}\text { 1996-1997 yıllarında Arjantin'de 16-29 } \\
\text { yaş arası düşük eğitimli gençlere yö- } \\
\text { nelik yürütülen eğitim programları- } \\
\text { nın katılımcılarına etkileri }\end{array}$ & $\begin{array}{l}\text { İstihdam } \\
\text { Ücret }\end{array}$ & $\begin{array}{l}\text { Pozitif etki, özel- } \\
\text { likle kadınlara }\end{array}$ \\
\hline $\begin{array}{l}\text { Alegre vd. } \\
2017\end{array}$ & $\begin{array}{l}\text { İspanya-Katalan bölgesinde, 2009- } \\
2013 \text { döneminde uygulanan mesleki } \\
\text { eğitim programlarının etkileri }\end{array}$ & İstihdam & $\begin{array}{l}\text { 16-18 yaş grubu } \\
\text { için pozitif, diğer- } \\
\text { leri sıfır veya ne- } \\
\text { gatif }\end{array}$ \\
\hline $\begin{array}{l}\text { Akhmedov, } \\
\text { vd. (2003) }\end{array}$ & $\begin{array}{l}\text { Rusya'da uygulanan A.İ.P.P. lerin et- } \\
\text { kileri }\end{array}$ & İstihdam & Negatif \\
\hline $\begin{array}{l}\text { Arellano, } \\
(2010)\end{array}$ & $\begin{array}{l}\text { 2000-2001 yıllarında İspanya' da uy- } \\
\text { gulanan mesleki eğitim programları- } \\
\text { nın etkileri }\end{array}$ & İşsizlik & $\begin{array}{l}\text { Negatif, önemsiz, } \\
\text { Kadınlara etkisi } \\
\text { daha fazla }\end{array}$ \\
\hline $\begin{array}{l}\text { Autor, House- } \\
\text { man, (2010) }\end{array}$ & $\begin{array}{l}\text { Detroit'te uygulanan refah programı- } \\
\text { nın etkileri }\end{array}$ & İstihdam & Pozitif \\
\hline $\begin{array}{l}\text { Benus, Rodri- } \\
\text { gez-Planas } \\
(2009)\end{array}$ & $\begin{array}{l}\text { 1990'dan sonra Romanya' da uygula- } \\
\text { nan A.I.P.P. larının etkileri }\end{array}$ & İstihdam & $\begin{array}{l}\text { Pozitif etki, } \\
\text { Kamu istihdam } \\
\text { hizmetlerinde ne- } \\
\text { gatif etki }\end{array}$ \\
\hline $\begin{array}{l}\text { Bergeman, } \\
\text { Pohlan, Uh- } \\
\text { lendorf, (2017) }\end{array}$ & $\begin{array}{l}\text { 1990-1999 yılları arasında Al- } \\
\text { manya'nın birleşmesinin ardından } \\
\text { Doğu Almanya'da uygulanan A.İ.P.P. } \\
\text { lerin etkileri }\end{array}$ & İstihdam & $\begin{array}{l}\text { Kisa dönem Pozi- } \\
\text { tif, Uzun dönem } \\
\text { etkisiz }\end{array}$ \\
\hline Blache, (2011) & $\begin{array}{l}\text { Danimarka'da uygulanan A.İ.P.P. le- } \\
\text { rin etkileri }\end{array}$ & $\begin{array}{l}\text { İstihdam } \\
\text { Ücret sevi- } \\
\text { yesi }\end{array}$ & Pozitif etki \\
\hline Bocean (2007) & $\begin{array}{l}\text { Romanya'da geçişten sonra, 2000- } \\
2005 \text { döneminde uygulanan A.İ.P.P. } \\
\text { lerin etkileri }\end{array}$ & İstihdam & Pozitif \\
\hline $\begin{array}{l}\text { Bonin, Rinne, } \\
\text { (2014) }\end{array}$ & $\begin{array}{l}\text { Serbest Piyasa Ekonomisine geçişden } \\
\text { sonra A.İ.P.P. olarak uygulanan Beau- } \\
\text { tiful Serbia programının etkileri }\end{array}$ & $\begin{array}{l}\text { İstihdam } \\
\text { Bireysel re- } \\
\text { fah }\end{array}$ & Pozitif \\
\hline $\begin{array}{l}\text { Bonnal vd. } \\
\text { (1997) }\end{array}$ & $\begin{array}{l}\text { 1986-1988 döneminde Fransa'da genç } \\
\text { işsizlere yönelik olarak uygulanan } \\
\text { eğitim programları }\end{array}$ & İstihdam & $\begin{array}{l}\text { Düşük eğitim se- } \\
\text { viyelerinde etkisiz }\end{array}$ \\
\hline $\begin{array}{l}\text { Calderon, } \\
\text { (2006) }\end{array}$ & $\begin{array}{l}\text { Meksika'da uygulanan A.İ.P.P. lerin } \\
\text { etkileri }\end{array}$ & İstihdam & $\begin{array}{l}\text { Kadınlar üzerinde } \\
\text { pozitif } \\
\text { Erkekler için etki- } \\
\text { siz }\end{array}$ \\
\hline
\end{tabular}




\begin{tabular}{|c|c|c|c|}
\hline $\begin{array}{l}\text { Caliendo, vd. } \\
\text { (2012) }\end{array}$ & $\begin{array}{l}\text { 2001-2008 yılları arasında Batı Al- } \\
\text { manya' da erkeklerin yararlandığı } \\
\text { A.İ.P.P. lerin etkileri }\end{array}$ & $\begin{array}{l}\text { İstihdam } \\
\text { Küçük } \\
\text { iş }\end{array}$ & Pozitif \\
\hline $\begin{array}{l}\text { Caliendo, } \\
\text { Künn, (2012) }\end{array}$ & $\begin{array}{l}\text { Almanya'da düşük nitelikli kadın iş- } \\
\text { çiler üzerinde uygulanan A.İ.P.P. le- } \\
\text { rin uzun dönem etkileri }\end{array}$ & $\begin{array}{l}\text { İstihdam } \\
\text { Ücret }\end{array}$ & Pozitif \\
\hline $\begin{array}{l}\text { Calmfors, } \\
\text { Forslund, } \\
\text { Hemström, } \\
(2001)\end{array}$ & $\begin{array}{l}\text { 1990'dan sonra İsveç'te uygulanan } \\
\text { A.İ.P.P.'larının etkilerini inceleyen ça- } \\
\text { lışmaların derlenmesi. }\end{array}$ & $\begin{array}{l}\text { İstihdam } \\
\text { Ücretler }\end{array}$ & $\begin{array}{l}\text { İstihdam etkisi (+) } \\
\text { Ücret etkisi belir- } \\
\text { siz }\end{array}$ \\
\hline $\begin{array}{l}\text { Caliendo vd, } \\
(2006)\end{array}$ & $\begin{array}{l}\text { Almanya' da özellikle zor işlerde çalı- } \\
\text { şan işçiler üzerine uygulanan A.İ.P.P. } \\
\text { lerin etkileri }\end{array}$ & İstihdam & Etki yok \\
\hline $\begin{array}{l}\text { Carling, Ric- } \\
\text { hardson, } \\
(2001)\end{array}$ & $\begin{array}{l}\text { 1995-1997 yılları arasında İsveç'te iş- } \\
\text { siz kalan yetişkinlerin katıldığı } \\
\text { A.İ.P.P. sonrasında işsizlik süresin- } \\
\text { deki azalma ölçülmüş }\end{array}$ & $\begin{array}{l}\text { İşsizlik sü- } \\
\text { resi }\end{array}$ & $\begin{array}{l}\text { İstihdam sübvan- } \\
\text { siyonları ve firma } \\
\text { eğitimlerinin etkisi } \\
\text { pozitif }\end{array}$ \\
\hline $\begin{array}{l}\text { Caroleo, } \\
\text { Patsore, (2017) }\end{array}$ & $\begin{array}{l}\text { İtalya'da genç işsizlere yönelik olarak } \\
\text { uygulanan A.I..P.P.lerin etkileri }\end{array}$ & İstihdam & Pozitif \\
\hline $\begin{array}{l}\text { Cocks, Bardo- } \\
\text { ulat, }(2000)\end{array}$ & $\begin{array}{l}\text { 1989-1993 döneminde Belçika'da } \\
\text { uygulanan meslek edindirme eğitim- } \\
\text { lerinin etkileri }\end{array}$ & İstihdam & Pozitif etki \\
\hline $\begin{array}{l}\text { Cockx vd. } \\
(1996)\end{array}$ & $\begin{array}{l}\text { 1991-1992 yıllarında Belçika'da } \\
\text { uygulanan A.İ.P.P. lerin etkileri }\end{array}$ & İstihdam & Pozitif \\
\hline $\begin{array}{l}\text { Crepon, Deje- } \\
\text { meppe, Gur- } \\
\text { gand, }(2005)\end{array}$ & $\begin{array}{l}2001 \text { yılından sonra Fransa'da uygu- } \\
\text { lanan A.İ.P.P. lerin etkileri }\end{array}$ & İstihdam & Pozitif önemsiz \\
\hline $\begin{array}{l}\text { Dahl, Lorent- } \\
\text { zen, (2005) }\end{array}$ & $\begin{array}{l}\text { Norveç'te } 1995 \text { yılında uygulanan } \\
\text { A.İ.P.P. lerin (iş arama yardımı, eği- } \\
\text { tim programı) etkileri }\end{array}$ & $\begin{array}{l}\text { İstihdam } \\
\text { Ücret }\end{array}$ & $\begin{array}{l}\text { İş arama yardımı- } \\
\text { nın istihdam etkisi } \\
\text { yok } \\
\text { Eğitimin istihdam } \\
\text { etkisi pozitif. } \\
\text { Ücret etkisi pozi- } \\
\text { tif. }\end{array}$ \\
\hline $\begin{array}{l}\text { Dar, Gill, } \\
(1998)\end{array}$ & $\begin{array}{l}\text { OECD ülkelerinde uygulanan A.İ.P.P. } \\
\text { lerin daha önce çalışmış ancak işten } \\
\text { çıarılmış kişiler üzerindeki etkisi }\end{array}$ & İstihdam & Etkisiz \\
\hline $\begin{array}{l}\text { Decker vd. } \\
(2000)\end{array}$ & $\begin{array}{l}\text { ABD'de } 1980^{\prime} \text { den sonra uygulanan iş } \\
\text { arama yardımı programlarının etki- } \\
\text { leri }\end{array}$ & $\begin{array}{l}\text { İstihdam } \\
\text { Ücret }\end{array}$ & $\begin{array}{l}\text { Önemli pozitif etki } \\
\text { bulunamadı }\end{array}$ \\
\hline $\begin{array}{l}\text { Dengler, } \\
(2013)\end{array}$ & $\begin{array}{l}\text { Almanya'da uygulanan A.İ.P.P. lerin } \\
\text { katılımclarına etkisi }\end{array}$ & İstihdam & Pozitif \\
\hline $\begin{array}{l}\text { Dorsett, vd. } \\
2013\end{array}$ & $\begin{array}{l}\text { İngiltere'de, uzun süredir işsiz olan } \\
50 \text { yaş üstü kişilere uygulanan } \\
\text { A.İ.P.P. lerin etkileri }\end{array}$ & $\begin{array}{l}\text { İstihdam } \\
\text { Ücret }\end{array}$ & $\begin{array}{l}\text { Pozitif, Uzun dö- } \\
\text { nemde negatif }\end{array}$ \\
\hline
\end{tabular}




\begin{tabular}{|c|c|c|c|}
\hline $\begin{array}{l}\text { Eicher, Lech- } \\
\text { ner, (2002) }\end{array}$ & $\begin{array}{l}\text { Doğu Almanya' da uygulanan A.İ.P.P. } \\
\text { lerin etkileri }\end{array}$ & İstihdam & Pozitif \\
\hline $\begin{array}{l}\text { Fitzenberger, } \\
\text { Prey, (2000) }\end{array}$ & $\begin{array}{l}\text { 1990-1994 yılları arasında Doğu Al- } \\
\text { manya'da uygulanan eğitim ve yeni- } \\
\text { den eğitim programlarının etkileri }\end{array}$ & $\begin{array}{l}\text { İstihdam } \\
\text { Ücretler }\end{array}$ & Pozitif \\
\hline $\begin{array}{l}\text { Galasso vd. } \\
(2001)\end{array}$ & $\begin{array}{l}\text { 1998-2000 döneminde Arjantin'de uy- } \\
\text { gulanan eğitim programlarının etki- } \\
\text { leri }\end{array}$ & $\begin{array}{l}\text { İstihdam } \\
\text { Ücret }\end{array}$ & $\begin{array}{l}\text { Önemsiz pozitif } \\
\text { etki }\end{array}$ \\
\hline $\begin{array}{l}\text { Gerfin, Lech- } \\
\text { ner, (2002) }\end{array}$ & $\begin{array}{l}\text { İsviçre' de } 1990 \text { 'll yıllarda uygulanan } \\
\text { A.İ.P.P. lerin etkileri }\end{array}$ & İstihdam & $\begin{array}{l}\text { Pozitif } \\
\text { Korumalı işgücü } \\
\text { piyasalarında ne- } \\
\text { gatif }\end{array}$ \\
\hline $\begin{array}{l}\text { Gerfin, vd. } \\
\text { (2005) }\end{array}$ & $\begin{array}{l}\text { İsviçrede uygulanan A.İ.P.P. lerin et- } \\
\text { kileri }\end{array}$ & İstihdam & $\begin{array}{l}\text { Nitelikli ve kısa } \\
\text { süreli işsizler için } \\
\text { negatif, uzun sü- } \\
\text { reli işsizler için } \\
\text { pozitif }\end{array}$ \\
\hline Giorgi, (2005) & $\begin{array}{l}\text { İngiltere'de } 18-24 \text { yaş arası gençlere } \\
\text { uygulanan A.İ.P.P. lerin etkileri }\end{array}$ & İstihdam & Pozitif \\
\hline $\begin{array}{l}\text { Graversen, } \\
\text { Ours, (2006) }\end{array}$ & $\begin{array}{l}\text { Danimarka'da Kasım 2005-Mart } 2006 \\
\text { arasında işsiz kalan bireylere uygula- } \\
\text { nan A.İ.P.P. lerin etkileri }\end{array}$ & İstihdam & Pozitif \\
\hline $\begin{array}{l}\text { Graves, Graut- } \\
\text { hier, (2017) }\end{array}$ & $\begin{array}{l}\text { Kanada'da uygulanan A.İ.P.P. lerin } \\
\text { etkileri }\end{array}$ & $\begin{array}{l}\text { İstihdam } \\
\text { Ücret }\end{array}$ & $\begin{array}{l}\text { Kisa dönemde po- } \\
\text { zitif önemli etki }\end{array}$ \\
\hline $\begin{array}{l}\text { Gritz, John- } \\
\text { son, (2001) }\end{array}$ & $\begin{array}{l}\text { ABD'de 1994-2000 döneminde 16-24 } \\
\text { yaş arası, eğitimsiz gençlere yönelik } \\
\text { uygulanan A.İ.P.P. lerin etkileri }\end{array}$ & $\begin{array}{l}\text { İstihdam } \\
\text { Ücret }\end{array}$ & Pozitif etki \\
\hline $\begin{array}{l}\text { Hagglund, } \\
(2009)\end{array}$ & $\begin{array}{l}\text { İsveç'te } 2004 \text { yllında uygulanan } \\
\text { A.İ.P.P. lerin etkileri }\end{array}$ & İstihdam & Pozitif önemsiz \\
\hline $\begin{array}{l}\text { Hamersma } \\
(2005)\end{array}$ & $\begin{array}{l}\text { Amerika Wisconsin eyaletinde uygu- } \\
\text { lanan A.İ.P.P. lerin etkileri }\end{array}$ & $\begin{array}{l}\text { İstihdam } \\
\text { Ücret }\end{array}$ & $\begin{array}{l}\text { Kisa dönemde po- } \\
\text { zitif, uzun dö- } \\
\text { nemde etkisiz }\end{array}$ \\
\hline $\begin{array}{l}\text { Hardoy, } \\
(2005)\end{array}$ & $\begin{array}{l}\text { 1989-1993 yılları arasında Norveç'te } \\
\text { uygulanan A.İ.P.P.'lerin } 16-25 \text { yaş } \\
\text { arası gençlerin istihdamına etkileri }\end{array}$ & $\begin{array}{l}\text { İşsizlik } \\
\quad \text { Tam } \\
\text { zamanlı is- } \\
\text { tihdam } \\
\text { Yarı za- } \\
\text { manlı istih- } \\
\text { dam }\end{array}$ & $\begin{array}{l}\text { İşsizliğe negatif, } \\
\text { yarı ve tam za- } \\
\text { manlı istihdama } \\
\text { pozitif etki }\end{array}$ \\
\hline $\begin{array}{l}\text { Hohmeyer, } \\
\text { Wolff, (2017) }\end{array}$ & $\begin{array}{l}\text { Almanya' da uygulanan A.İ.P.P. lerin } \\
\text { etkileri }\end{array}$ & $\begin{array}{l}\text { İstihdam } \\
\text { Ücret }\end{array}$ & $\begin{array}{l}\text { Kisa dönem pozi- } \\
\text { tif, uzun dönem } \\
\text { belirsiz }\end{array}$ \\
\hline $\begin{array}{l}\text { Hollenback, } \\
(2003)\end{array}$ & $\begin{array}{l}\text { Washington'da uygulanan işgücü ge- } \\
\text { liştirme eğitimlerinin etkileri. 1997-98 } \\
\text { için uzun dönem, 1999-2000 için kısa } \\
\text { dönem etki analizi yapılmış }\end{array}$ & İstihdam & $\begin{array}{l}\text { Uzun dönemde } \\
\text { pozitif, K1sa dö- } \\
\text { nemde bazı prog- } \\
\text { ramlar pozitif, }\end{array}$ \\
\hline
\end{tabular}




\begin{tabular}{|c|c|c|c|}
\hline & & & $\begin{array}{l}\text { bazı programlar } \\
\text { negatif }\end{array}$ \\
\hline $\begin{array}{l}\text { Jacob, Petta, } \\
(2000)\end{array}$ & $\begin{array}{l}\text { 1987-1998 döneminde } \mathrm{ABD}^{\prime} \text { de uygu- } \\
\text { lanan Kamu istihdam hizmetlerine } \\
\text { yerleşenlerin fayda-maliyet analizi }\end{array}$ & $\begin{array}{l}\text { İstihdam } \\
\text { Ücret }\end{array}$ & Pozitif etki \\
\hline $\begin{array}{l}\text { Jaenichen, } \\
\text { Stephan, } \\
(2011)\end{array}$ & $\begin{array}{l}\text { Almanya' da uygulanan A.İ.P.P. lerin } \\
\text { etkileri }\end{array}$ & İstihdam & Pozitif \\
\hline $\begin{array}{l}\text { Jalan, Raval- } \\
\text { lion, (2003) }\end{array}$ & $\begin{array}{l}\text { Arjantin'de uygulanan A.İ.P.P.lerin } \\
\text { düşük ücretler üzerindeki etkileri }\end{array}$ & Ücret & Pozitif \\
\hline $\begin{array}{l}\text { Jespersen, } \\
\text { Munch, Skip- } \\
\text { per, (2008) }\end{array}$ & $\begin{array}{l}\text { 1995-2005 yılları arasında Dani- } \\
\text { marka' da uygulanan A.İ.P.P. lerin et- } \\
\text { kileri }\end{array}$ & $\begin{array}{l}\text { İstihdam } \\
\text { Ücret }\end{array}$ & Pozitif \\
\hline $\begin{array}{l}\text { Kastoryano, } \\
\text { Klaauw, } \\
(2011)\end{array}$ & $\begin{array}{l}1 \text { Ağustos 2006-1 Nisan } 2008 \text { arasında } \\
30 \text { günden fazla işsiz kalan bireylere } \\
\text { yönelik, Hollanda'da yapılan iş arama } \\
\text { yardımlarının etkileri }\end{array}$ & İstihdam & $\begin{array}{l}\text { Kisa dönemde et- } \\
\text { kisiz, uzun dö- } \\
\text { nemde önemsiz } \\
\text { etki }\end{array}$ \\
\hline $\begin{array}{l}\text { Karaginnaki, } \\
(2006)\end{array}$ & $\begin{array}{l}\text { Nisan } 2002 \text { de İngiltere' de A.İ.P.P. uy- } \\
\text { gulamalarında yapılan değişikliklerin } \\
\text { etkileri }\end{array}$ & İstihdam & $\begin{array}{l}\text { İşçileri için pozitif, } \\
\text { İşletmeler açısın- } \\
\text { dan negatif }\end{array}$ \\
\hline $\begin{array}{l}\text { Kluve vd. } \\
(1999)\end{array}$ & $\begin{array}{l}\text { 1992-1996 döneminde Polonyada uy- } \\
\text { gulanan eğitim programlarının etki- } \\
\text { leri }\end{array}$ & İstihdam & $\begin{array}{l}\text { Pozitif. Önemli } \\
\text { etki }\end{array}$ \\
\hline Kolev, (2003) & $\begin{array}{l}\text { Bulgaristan'da } 1990^{\prime} \text { dan sonra uygu- } \\
\text { lanan A.İ.P.P. lerin etkileri }\end{array}$ & $\begin{array}{l}\text { İstihdam } \\
\text { Ücret }\end{array}$ & Pozitif \\
\hline $\begin{array}{l}\text { Kraus vd. } \\
(1999)\end{array}$ & $\begin{array}{l}\text { 1992-1994 döneminde Almanya' da } \\
\text { yeniden eğitim programlarının etki- } \\
\text { leri }\end{array}$ & İstihdam & Pozitif \\
\hline $\begin{array}{l}\text { Larsson, } \\
(2000)\end{array}$ & $\begin{array}{l}\text { İsveç'te gençlere yönelik olarak uygu- } \\
\text { lanan işgücü piyasası eğitim prog- } \\
\text { ramlarının etkinliği }\end{array}$ & İstihdam & $\begin{array}{l}\text { Kısa dönemde } \\
\text { olumsuz, uzun } \\
\text { dönemde sıfır } \\
\text { veya pozitif önem- } \\
\text { siz }\end{array}$ \\
\hline $\begin{array}{l}\text { Lechner, } \\
(2000)\end{array}$ & $\begin{array}{l}\text { 1990-1996 döneminde Almanya'da } \\
\text { uygulanan eğitim programlarının et- } \\
\text { kileri }\end{array}$ & İstihdam & Pozitif \\
\hline $\begin{array}{l}\text { Lechner, } \\
\text { Miquel, } \\
\text { Wunsch, } \\
(2007) \\
\end{array}$ & $\begin{array}{l}\text { Doğu Almanya'nin geçiş sürecinde } \\
\text { uygulanan A.İ.P.P. lerin etkileri }\end{array}$ & $\begin{array}{l}\text { İstihdam } \\
\text { Ücret }\end{array}$ & $\begin{array}{l}\text { Pozitif } \\
\text { Uzun dönemde er- } \\
\text { kekler açısından } \\
\text { negatif }\end{array}$ \\
\hline $\begin{array}{l}\text { Lise, vd. } \\
(2004)\end{array}$ & $\begin{array}{l}\text { Kanada'da uygulanan Self-Sufficient } \\
\text { Programının etkileri }\end{array}$ & Ücretler & Pozitif \\
\hline $\begin{array}{l}\text { Medina, Nu- } \\
\text { nez, (2005) }\end{array}$ & $\begin{array}{l}\text { 1996-1997 yıllarında Kolombiya'da } \\
\text { SENA programı kapsamında uygula- } \\
\text { nan A.İ.P.P. lerin etkinliği }\end{array}$ & $\begin{array}{l}\text { İstihdam } \\
\text { Ücret }\end{array}$ & $\begin{array}{l}\text { Pozitif önemsiz } \\
\text { etki. Kısa dö- }\end{array}$ \\
\hline
\end{tabular}




\begin{tabular}{|c|c|c|c|}
\hline & & & $\begin{array}{l}\text { nemde daha az et- } \\
\text { kili, ücretlere et- } \\
\text { kisi yok }\end{array}$ \\
\hline $\begin{array}{l}\text { Mihaylov, } \\
\text { (2011) }\end{array}$ & $\begin{array}{l}\text { Bulgaristan'da uygulanan A.I.P.P. le- } \\
\text { rin uzun dönem etkileri }\end{array}$ & İstihdam & Pozitif \\
\hline $\begin{array}{l}\text { Nivorozhkin, } \\
\text { Nivorozhkin, } \\
(2005)\end{array}$ & $\begin{array}{l}\text { Rusya'da kentsel alanda yaşayan bi- } \\
\text { reylere yönelik olarak uygulanan } \\
\text { A.İ.P.P. lerin etkileri }\end{array}$ & İstihdam & $\begin{array}{l}\text { Negatif etkiye } \\
\text { rastlanmamış }\end{array}$ \\
\hline Olga, (2000) & $\begin{array}{l}\text { Ukrayna' da uygulanan A.İ.P.P. lerin } \\
\text { etkileri }\end{array}$ & İstihdam & Pozitif \\
\hline $\begin{array}{l}\text { Park vd. } \\
(1996)\end{array}$ & $\begin{array}{l}\text { 1988-1991 yılları arasında Kanada'da } \\
\text { uygulanan beceri eğitim programları } \\
\text { ile iş geliştirme desteklerinin etkileri }\end{array}$ & İstihdam & $\begin{array}{l}\text { Pozitif ancak } \\
\text { önemsiz etki }\end{array}$ \\
\hline Payne, (2000) & $\begin{array}{l}\text { 1995-1997 döneminde İngiltere'de ye- } \\
\text { tişkinlerin beceri eğitimi programları- } \\
\text { nın etkileri }\end{array}$ & $\begin{array}{l}\text { İstihdam } \\
\text { Ücret }\end{array}$ & $\begin{array}{l}\text { İstihdam pozitif, } \\
\text { Ücret etkisiz }\end{array}$ \\
\hline $\begin{array}{l}\text { Pfeiffer, } \\
\text { Reize, (2000) }\end{array}$ & $\begin{array}{l}\text { Almanya'da Start-Up programların- } \\
\text { dan faydalanan firmalar açısından } \\
\text { uygulanan A.İ.P.P. lerin etkileri }\end{array}$ & İstihdam & Negatif \\
\hline Prey, (2000) & $\begin{array}{l}\text { Ocak-Nisan } 1998 \text { döneminde İsviçre } \\
\text { Kantonu St.Gallen'de uygulanan Al- } \\
\text { manca dil ve bilgisayar eğitimlerinin } \\
\text { etkileri }\end{array}$ & $\begin{array}{l}\text { Kisa dö- } \\
\text { nem istih- } \\
\text { dam }\end{array}$ & Pozitif \\
\hline $\begin{array}{l}\text { Raaum, Torp, } \\
\text { (2002) }\end{array}$ & $\begin{array}{l}\text { 1989-1994 döneminde Norveç'te uy- } \\
\text { gulanan mesleki eğitim programlar1- } \\
\text { nın etkileri }\end{array}$ & $\begin{array}{l}\text { İstihdam } \\
\text { Ücret }\end{array}$ & Pozitif \\
\hline Reenen (2003) & $\begin{array}{l}\text { 1998-2000 yıları arasında İngiltere'de } \\
\text { düşük nitelikli ve az eğitimli kişilere } \\
\text { uygulanan A.İ.P.P. lerin genç istihda- } \\
\text { mına etkileri }\end{array}$ & $\begin{array}{l}\text { İstihdam } \\
\text { Ücret }\end{array}$ & $\begin{array}{l}\text { Pozitif etki } \\
\text { Kadınlar açısın- } \\
\text { dan önemsiz etki }\end{array}$ \\
\hline $\begin{array}{l}\text { Richardson, } \\
\text { Berg, } 2006\end{array}$ & $\begin{array}{l}\text { Mesleki eğitim kurslarının (AMU), } \\
\text { 1993-2000 yılları arasında İsveç'te iş- } \\
\text { siz kalan bireylere etkileri }\end{array}$ & İstihdam & Önemli pozitif etki \\
\hline $\begin{array}{l}\text { Rodokanakis, } \\
\text { Moustaki, } \\
(2010)\end{array}$ & $\begin{array}{l}\text { Yunanistenda 1989-2003 yıllarında } \\
\text { uygulanan A.İ.P.P. lerin etkileri }\end{array}$ & İstihdam & Etkisiz \\
\hline $\begin{array}{l}\text { Ronsen, Ska- } \\
\text { rohamar, } \\
(2009)\end{array}$ & $\begin{array}{l}\text { Norveç'te uygulanan A.İ.P.P. lerin et- } \\
\text { kileri }\end{array}$ & İstihdam & $\begin{array}{l}\text { Uzun dönem sos- } \\
\text { yal yardım alanlar } \\
\text { için pozitif, göç- } \\
\text { menler ve tek ka- } \\
\text { dınlar için etkisiz, } \\
\text { gençler için nega- } \\
\text { tif }\end{array}$ \\
\hline $\begin{array}{l}\text { Rosholm, Sva- } \\
\text { rer, (2004) }\end{array}$ & $\begin{array}{l}\text { 1998-2002 yılları arasında Dani- } \\
\text { marka' da uygulanan A.İ.P.P. lerin et- } \\
\text { kileri }\end{array}$ & İstihdam & Pozitif güçlü etki \\
\hline
\end{tabular}




\begin{tabular}{|c|c|c|c|}
\hline "Sianesi, (2005) & $\begin{array}{l}1994-1999 \text { yılları arası İsveç'te iş } \\
\text { arama yardımı ve mesleki eğitimler- } \\
\text { den faydalanan } 25 \text { yaş üstü yetişkinle- } \\
\text { rin istihdam durumu }\end{array}$ & İंstihdam & $\begin{array}{l}\text { Kisa dönemde ne- } \\
\text { gatif, orta ve uzun } \\
\text { dönemde pozitif } \\
\text { etki }\end{array}$ \\
\hline $\begin{array}{l}\text { Stephan, } \\
(2008)\end{array}$ & $\begin{array}{l}\text { Almanya'da } 2003 \text { yılından sonra uy- } \\
\text { gulanan A.İ.P.P. lerin etkileri }\end{array}$ & İstihdam & $\begin{array}{l}\text { Pozitif önemsiz } \\
\text { etki }\end{array}$ \\
\hline $\begin{array}{l}\text { Stephan, } \\
\text { Pahnke, (2011) }\end{array}$ & $\begin{array}{l}\text { Almanya'da uygulanan A.İ.P.P. lerin } \\
\text { etkileri }\end{array}$ & İstihdam & $\begin{array}{l}\text { Kısa süreli prog- } \\
\text { ramlar daha etkili } \\
\text { pozitif }\end{array}$ \\
\hline $\begin{array}{l}\text { Stromback vd. } \\
\text { (1999) }\end{array}$ & $\begin{array}{l}\text { 1993-1996 yılları arasında, Avust- } \\
\text { ralya'da uygulanan A.İ.P.P. lerin etki- } \\
\text { leri }\end{array}$ & $\begin{array}{l}\text { İstihdamda } \\
\text { kalma }\end{array}$ & $\begin{array}{l}\text { Önemli pozitif etki } \\
\text { bulunamadı }\end{array}$ \\
\hline $\begin{array}{l}\text { Terrel, Storm, } \\
\text { (1999) }\end{array}$ & $\begin{array}{l}\text { Çekya'da, geçişten sonra uygulanan } \\
\text { A.İ.P.P. ve işsizlik telafi sistemlerinin } \\
\text { Çek nüfusu üzerindeki etkileri analiz } \\
\text { edilmiş }\end{array}$ & İstihdam & Pozitif etki \\
\hline $\begin{array}{l}\text { Vangjeli, } \\
\text { Stillo, Te- } \\
\text { neqexhi, } \\
(2012)\end{array}$ & $\begin{array}{l}\text { 1999-2010 yilları arasinda Arnavut- } \\
\text { luk'ta uygulanan A.İ.P.P. lerin etkileri }\end{array}$ & İstihdam & Pozitif etki \\
\hline $\begin{array}{l}\text { Vodopivec, } \\
\text { (1999) }\end{array}$ & $\begin{array}{l}\text { Slovakya'da 1992-1996 yılları ara- } \\
\text { sında uygulanan A.İ.P.P. lerin etkileri } \\
\text { (uzun dönemde damgalanma etkisi) }\end{array}$ & İstihdam & $\begin{array}{l}\text { Kisa dönemde po- } \\
\text { zitif, uzun dö- } \\
\text { nemde negatif }\end{array}$ \\
\hline $\begin{array}{l}\text { Webster, John- } \\
\text { son, (2001) }\end{array}$ & $\begin{array}{l}\text { 1995-1997 yılları arasında Avust- } \\
\text { ralya'da uygulanan A.İ.P.P. larının et- } \\
\text { kilerinin düşük gelirli ve düşük eği- } \\
\text { timli (dezavantajlı) kişilerle, yüksek } \\
\text { sağlık ve eğitim harcamasında bulu- } \\
\text { nan kişiler arasındaki etkilerinin kar- } \\
\text { şılaştırılması }\end{array}$ & İstihdam & Pozitif \\
\hline $\begin{array}{l}\text { Winterhager, } \\
\text { vd. (2006) }\end{array}$ & $\begin{array}{l}\text { Batı Almanya' da uygulanan A.İ.P.P. } \\
\text { lerin etkileri }\end{array}$ & İstihdam & Pozitif \\
\hline $\begin{array}{l}\text { Wolterman, } \\
(2002)\end{array}$ & $\begin{array}{l}1999 \text { yılında Brezilya'da iş arama hiz- } \\
\text { metlerinin etkileri }\end{array}$ & İstihdam & Negatif etki \\
\hline
\end{tabular}

\section{Ek-2}

\section{META ANALIZDE KULLANILAN KAYNAKLAR}

Aedo, C. Ve Nunez, S. (2004). The İmpact Of Training Policies İn Latin America And The Caribbean: The Case Of Programa Joven. Inter American Development Bank Research Network Working Paper R-483 
Akhmedov, A., Denisova, I.A. Ve Kartseva. M. (2003). Active Labor Market Policies İn Russia: Regional Interpretation Determines Effectiveness? Moscow: Center For Economic And Financial Research And New Economic School. Erişim: Http://Www.Cefir.Ru/Papers/Wp37.Pdf. Erişim Tarihi: 14/09/2017

Alegre, M.A., Todeschinı, F.A., Casado, D. Ve Sanz, J. The İmpact Of Training-İntensive Labour Market Policies On Neet's Labour And Educational Prospect: Evidence From Catalonia (Spain). Catalan Institute Of Public Policy Evaluation, Erişim: Https://Editorialexpress.Com/Cgibin/Conference/Download.Cgi?Db Name=CompleEPaper İd $=61$ Erişim Tarihi:12/09/2017

Arellano, F.A. (2010). Do Training Programmes Get The Unemployment Back To Work? A Look At The Spanish Experience. Revista De Economia Aplicade, No:53, V.Xvun, P.39-65

Autor, D.H. Ve Houseman, S.N. (2010). Do Temporary-Help Jobs İmprove Labor Market Outcomes For Low-Skilled Workers? Evidence From “Work First. American Economic Journal, Erişim:Https://Economics.Mit.Edu/Files/596, Erişim Tarihi: 12/09/2017

Benus, J., Rodrigez-Planas. (2009). Evaluation Active Labour Market Program İn Romania. Empir Econ (2010) 38: 65-84

Bergemann, A., Pohlan, L. Ve Uhlendorf, A. (2017). The İmpact Of Participation İn Job Creation Schemes İn Turbulent Times. Ifau Working Paper 7

Blache, G. (2011). Active Labour Market Policies İn Denmark: A Comperative Analiysis Of Post Program Effects. Ces Working Paper No:71

Bocean, C.G. (2007). The Impact Of Active Labour Market Policies İn Romania. Munich Personal Repec Archive (Mpra) Paper No. 10397. Erişim: $\quad$ Http://Mpra.Ub.Unimuenchen.De/10397/1/Mpra Paper 10397.Pdf. Erişim Tarihi: 14/09/2017

Bonın, H. Ve Rinne, U. (2014). Beautiful Serbia - Objective And Subjective Outcomes Of Active Labour Market Policy İn A Transition Economy. Economics Of Transition 22(1), 43-67.

Bonnal, L., Fougere, D. Ve Serandon A. (1997). Aveluating The İmpact Of French Employment Policies On İndividual Labour Market Histories. The Review Of Economic Studies, Vol.64 No.4 
Calderón, M.A. (2006). Revisiting The Employability Effects Of Training Programs For The Unemployed İn Developing Countries. Erişim: Http://Www.Iadb.Org/Res/Publications/Pubfiles/Pubr-522.Pdf. Erişim Tarihi: 14/09/2017

Calıendo, M., Künn, S. Ve Uhlendorf, A. (2012). Marginal Employment Duration And Job Match Quality. Iza Dp No:6499

Calıendo, M. Ve Künn, S. (2012). Getting Back İnto The Labour Market: The Effects Of Start-Up Subsidies For Unemployment Females. Iza $D p$ No:6830

Calıendo, M., Hujer, R., Ve Thomsen, S.L. (2006). Sectoral Heterogeneity In The Employment Effects Of Job Creation Schemes İn Germany. Iab Discussion Paper No.13/2005

Calmfors, L., Forslund, A. Ve Hemström, M. (2001). Does Active Labour Market Policy Work? Lesson From The Swedish Experience. Swedish Economic Policy Review 85, 61-124

Caroleo, F. Ve Pastore, F. How Fine Targeted İs Almp To The Youth Long Term Unemployed İn Italy. Erişim: Http://Www.Aiel.Itt/Old/Bacheca/Furenze/Papers/Caroleo Pastore.Pdf, Erişim Tarihi: 13/09/2017

Carlıng, K. Ve Richardson, K. (2001). The Relative Efficiency Of Labour Market Programs: Swedesh Experience From 1990's. Ifau Working Paper 2001:2

Cocks, B. Ve Bardoulat, I. (2000). Vocational Training: Does İt Speed Up The Transition Rate Out Of Unemployment? Econpaper Dp, 9932

Cockx, B., Linden, B. Ve Karaa, A. (1996). Active Labour Market Policies And Job Tenure. Erişim: Http://Sites-Test.Uclouvain.Be/Econ/Dp/Ires/9626.Pdf, Erişim Tarihi: 12/09/2017

Crepon, B., Dejemeppe, M. Ve Gurgand, M. (2005). Counseling The Unemployed: Does İt Lower Unemployment Duration And Recurrence? Iza $D p$ No.1796

Dahl, E.Ve Lorentzen, T. (2005). What Works For Whom? An Analysis Of Active Labour Market Programmes İn Norway. International Journal Of Social Welfare, V.14, Issue.2, P.86-98

Decker, P., Olsen, R. Ve Freeman, L. (2000). Assisting Unemployment Insurance Claimants: The Long-Term Impacts Of The Job Search Assistance Demonstration. Mathematica Policy Research. Washington, D.C. 
Dengler, K. (2013). Effectiveness Of Sequences Of One-Euro-Jobs: Is İt Better To Do More One-Euro-Jobs Or To Wait? Iab Discussion Paper No.16

Dorsett, R., Smeaton, D. Ve Speckesser, S. (2013). The Effect Of Making A Voluntary Labour Market Programme Compulsory: Evidence From A Uk Experiment. Fiscal Studies, Vol.34, No.4,Pp.467-489

Eıchler, M. Ve Lechner, M. (2002). An Evaluation Of Public Employment Programmes İn East German State Of Sachsen-Anhalt. Labour Economics: An International Journal, 9, 143-186

Fitzenberger, B. Ve Prey, H. (2000). Evaluating Public Sector Sponsored Training İn East Germany. Oxford Economic Papers 52, 497-520

Galasso, E., Ravallıon, M. Ve Salvıa, A. (2001). Assisting The Transition From Workfare To Work: Argentina's Proempleo Experiment. Erişim: Https://Www.Researchgate.Net/Publication/255580112, Erişim Tarihi: 07/09/2017

Gerfın, M. Ve Lechner, M. (2002). A Microeconometric Evaluation Of The Active Labour Market 7

Policy İn Switzerland. The Economic Journal, V.112, Issue 482, Pp.854-893

Gerfın, M., Lechner, M. Ve Steiger, H. (2005). An Econometric Analysis Of Two Different Schemes. Labour Economics-An International Journal, $12,807-835$

Giorg1, G.D. (2005). The New Deal For Young People Five Years On. Fiscal Studies, Volume 26, Issue 3, Pp.371-383

Graves, F. Ve Gauther, B. Evaluation Of The Self-Employment Assistance Program. Macro Evaluation And Data Development Strategic Policy Human Resources Development Canada,Erişim: http://publications.gc.ca/collections/collection 2013/rhdcc-hrsdc/RH64-87-1999eng.pdf, Erişim Tarihi: 11/09/2017

Graversen, B.K. Ve Ours, J.C. (2006). How To Help Unemployed Find Jobs Quickly: Experimental Evidence From A Mandatory Activation Program. Iza Dp No:2504

Gritz, R.M. Ve Johnson, T. (2001). National Job Corps Study: Assessing Program Effects On Earnings For Students Achieving Key Program Milestones. U.S. Department Of Labor, Employment And Training Administration. Contract Number K-4279-3-00-80-30 
Hagglund, P. (2009). Experimental Evidence From İntensified Placement Efforts Among Unemployed İn Sweden. Ifau Working Paper 16

Hamersma, S. (2005). The Effects Of An Employer Subsidy On Employment Outcomes: A Study Of The Work Opportunity And Welfare To Work Tax Credits. Institute For Reaserch On Poverty Discussion Paper No.1303-05

Hardoy, I. (2005). Impact Of Labour Market Programmes On Multiple Outcomes:The Case Of Norwegian Youth Programmes. Erişim: Www.Reaserchgate.Net/Publication/4994035

Hohmeyer, K. Ve Wolff, J. Direct Job Creation İn Germany Revisited: Is İt Effective For Welfare Recipients And Does İt Matter Whether Participiant Receive A Wage?. Erişim: Http://Doku.İab.De/Veranstaltungen/2010/5.2_Joachim\%20wolff.Pdf, Erişim Tarihi: 13/09/2017

Hollenbeck, K. (2003). Net İmpact Estimates Of The Workforce Development System İn Washingtonstate. Upjohn Institute Working Paper No.03-92

Jaenichen, U. Ve Stephan, G. (2011). The Effectiveness Of Targeted Wage Subsidies For Hard-To-Place Workers. Erişim: Https://Hal.ArchivesOuvertes.Fr/Hal-00582284/Document, Erişim Tarihi:13/09/2017

Jacob, L. Ve Petta, I. (2000). Measuring The Effect Of Public Labor Exchange Referrals And Placements İn Washington And Oregon. Westat. Maryland. Erişim: Http://Wdr.Doleta.Gov/Owsdrr/006/006.Pdf

Jalan, J. Ve Ravillıon, M. (2003). Estimating The Benefit İncidence Of An Antipovertiy Program By Propensity-Score Matching. Journal Of Business E Economic Statistics, Vol.21, No.1, Pp.19-30

Jespersen, S.T., Munch, J.R. Ve Skıpper, L. (2008). Cost And Benefit Of Danish Active Labour Market Programmes. Elsevier Labour Economics 15, Pp.859-884

Karagiannakı, E. (2006). Exploring The Effects Of İntegrated Benefit System And Active Labour Market Policies: Evidence From Jobcentre Plus İn The Uk. Erişim: Http://Eprints.Lse.Ac.Uk /6240/1/Exploring The Effects_Of Integrated Benefit Systems And_Active Labour Market Policies Evidence From Jobcentre Plus In The Uk.Pdf, Erişim Tarihi:13/09/2017 
Kastoryano, S. Ve Klaauw, B. (2011). Dynamic Evaluation Of Job Search Assistance. Iza Dp No.5424

Kluve, J. (2014). Active Labour Market Policy With A Focus On Youth. European Training Foundation

Kluve, J., Lehman, H. Ve Schmıdt, C.M. (1999). Active Labour Market Policies İn Poland: Human Capital Enhancement, Stigmatization Or Benefit Churning? Journal Of Comperative Economics, V.27, Issue 1, P.61-89

Kolev, A. (2003). Joblessness And Precarious Work İn Bulgaria: Addressing The Multiple Aspects Of Vulnerability İn The Labour Market. Erişim: Http://Siteresources.Worldbank.Org/

Socialprotection/Resources/Spdiscussion-Papers/Labor-Market-Dp/0303.Pdf. Erişim Tarihi: 14/09/2017

Larsson, L. (2000). Evaluation Of Swedish Youth Labour Market Programmes. Erişim: Http://Www.Ifau.Se/Globalassets/Pdf/Se/To2000/Wp001.Pdf, Erişim Tarihi: 09/07/2017

Lechner, M. (2000). An Evaluation Of Public-Sector-Sponsored Continuous Vocational Training Programs İn East Germany. Journal Of Human Resources, Vol.35, Issue 2, 347-375

Lechner, M., Miquel, R. Ve Wunsch, C. (2007). The Curse And Blessing Of Training The Unemployed İn A Changing Economy: The Case Of East Germany After Unification. German Economic Review, 8, 468507

Lise, J., Seitz, S. Ve Smith, J. (2004). Equilibrium Policy Experiments And The Evaluation Of Social Programs. Nber Working Paper No:10283

Medina, C. Ve Nunez, J. (2005). The Impact Of Public And Private Job Training İn Colombia. Inter-American Development Bank Research Network Paper R-484

Mihaylov, E. (2011). Evaluation Of Subsidized Employment Programs For Long-Term Unemployed İn Bulgaria. Economic Studies Journal, (3), 136-167.

Nivorozhkın, A. Ve Nivorozhkın, E. (2007). Do Goverment Sponsored Vocational Training Programs Help The Unemployed Find Jobs? Evidence From Russia. Applied Economics Letter, 14 
Olga, K. (2000). The İmpact Of Active Labour Market Policies On The Outflows From Unemployment To Regular Jobs İn Ukraine. National University, Kiev-Mohyla Academy, Eerc Ma Programme In Economics, Master Thesis

Park, N., Power, B., Riddell, W.,C. Ve Wong, G. (1996).An Assestment Of The İmpact Of Government-Sponsored Training. Canadian Journal Of Economics, 0008-4085/96/93-98

Payne, J. (2000). Evaluating Training Programmes For Long Term Unemployed: An Illustration Of The Matched Comparison Group Methodology. Erişim: Https://İdeas.Repec.Org/P/Psi /Resdis/1.Html, Erişim Tarihi: 05/09/2017

Pfeiffer, H. Ve Reize, F. (2000). Business Start-Ups By The UnemployedAn Econometric Analysis Based On Firm Data. Elsevier, Vol.7, Issue 5, P.629-663

Prey, H. (2000). Evaluation Of Training Programs İn St.Gallen, Switzerland. Erişim: Https://İdeas.Repec.Org/A/Ses/Arsjes/2000-Iii-12.Html, Erişim Tarihi: 07/09/2017

Raam, O. Ve Torp, H. (2002). Labour Market Training İn Norway-Effect On Earnings. Elsevier V.9,P.207-247

Richardson, K. Ve Berg, G.J. (2006). Swedish Labour Market Training And The Duration Of Unemployment. Iza Dp No:2314

Reenen, J. (2003). Active Labour Market Policies And The British New Deal For The Young Unemployed İn Context. Nber Working Paper Series. Working Paper 9576.

Rodokanakıs, S. Ve Moustak1, I. (2010). Evaluating The Risk Of Unemployment: Comparision Between The Two Most Populated Greek Regions With The Entire Country. Regional Inquiry Journal, Issue Il, 1, Pp.71-87

Ronsen, M. Ve Skarohamar, T. (2009). Do Welfare To Work İnitiatives Work? Evidence From An Activation Programme Targeted At Social Assistance Recipient İn Norway. Journal Of European Social Policy, Vol.19, Issue 1

Rosholm, M. Ve Svarer, M. (2004). Estimating The Threat Effect Of Active Labour Market Programmes. Iza Dp No:1300 
Sianes1, B. (2005). Differential Effects Of Swedish Active Labour Market Programmes For Unemployment Adults During The 1990's. The Institutional For Fiscal Studies Wp01/25

Stephan, G. (2008). The Effect Of Active Labor Market Programs İn Germany. Iab Discussion Paper, 12

Stephan, G. Ve Pahnke, A. (2011). The Relative Effectiveness Of Selected Active Labor Market Programs: An Empirical İnvestigation For Germany. The Manchester School 79(6), 1262-1293.

Stromback, T. Dockery, A. M. Ve Ying, W. (1999). Labour Market Programs And Labour Force Status. Australian Bulletin Of Labour 25, No. 2: 159-78.

Terrell, K. Ve Sorm, V. (1999). Labor Market Policies And Unemployment İn The Czech Republic. Journal Of Comparative Economics 27, No. 1: 33-60.

Vangjel1, E., Stıllo, S. Ve Teneqexh1, M. (2012). Impact Of Labour Market Programs On Employment: Albenia Case. Scientific Paper Issue 8

Vodopivec, M. (1999). Does The Slovenian Public Work Program İncrease Participants' Chances To Find A Job? Journal Of Comparative Economics, V.27, Issue 1, P.113-130

Webster, E. Ve Johnson, D. (2001). An Estimate Of The Equity Effects Of Labour Market Programs. Melbourne Institute Working Paper No.1/01

Winterhager, H., Heınze, A. Ve Spermann, A. (2006). Deregulating Job Placement İn Europe: A Microeconometric Evaluation Of An İnnovative Voucher Scheme İn Germany. Iza Discussion Paper 2109

Wolterman, S. (2002). Job-Search Methods And Labour Market Transition In A Segmented Economy Some Empricial Evidence From Brazil. Econstore Discussion Paper No:88.

\section{Kaynakça Bilgisi / Citation Information}

Yavuz, H. B. (2017). Aktif işgücü piyasası politika uygulamalarının etkilerinin değerlendirilmesi: bir meta analiz çalışması. OPUS Uluslararası Toplum Araştırmaları Dergisi, 7(13), 497-523. 